\title{
An improved method for detecting faecal Vibrio cholerae by PCR of the toxin A gene
}

\author{
KAZUFUMI MIYAGI*†, KOUICHI SANO*, CHIZUKO MORITA*, SHUNRO IMURA* $\ddagger \|$, SHINICHI \\ MORIMATSU*, TOSHIYUKI GOTO*, YASUO NAKANO,+ KANZO OMURA $\$$, YASUKAZU \\ MATSUMOTO $\ddagger$ KENJI MAEDA $\ddagger$ SATORU HASHIMOTO $\ddagger$ and TAKESHI HONDA§ \\ * Department of Microbiology, Osaka Medical College, 569-8686 Osaka, †Osaka Quarantine Station, 552-0021 \\ Osaka, †Kansai (formerly Osaka) Airport Quarantine Station, 549-0011 Osaka and §Research Institute for \\ Microbial Diseases, Osaka University, 565-0871 Osaka, Japan
}

\begin{abstract}
A method for removing inhibitor(s) of the PCR assay for the direct detection of cholera toxin $A$ gene $(\operatorname{ctx} A)$ in human faeces is described. Inhibitors of the PCR were removed by centrifugation and the activity of the remaining inhibitors by dilution. Based on these data, a protocol was developed for pre-treatment of stool specimens for PCR assay, and a simple and rapid protocol was constructed for the diagnostic detection of the $\operatorname{ctx} A$ genes in stool specimens in combination with single band detection on gel electrophoresis, dot-blot hybridisation and enrichment culture. This protocol was applied to clinical specimens and showed that the PCR method gave $100 \%$ agreement with established culture methods for the detection of cholera toxin-producing Vibrio cholerae $\mathrm{O1}$. This protocol was considered to be useful because of its simplicity and the rapidity of diagnosis.
\end{abstract}

\section{Introduction}

Without proper diagnosis and treatment, cholera is a lethal disease and may be imported into non-endemic areas. The seventh pandemic of cholera with a mortality rate of $4.7 \%$ has been experienced in Asia, South America and Africa, and the total number of cases reported by the World Health Organization (WHO) is 143349 [1]. The WHO also reported that the mortality due to cholera was 6689 in 1996 [2]. The majority of cases of cholera in Japan (89\%) are imported from endemic areas. To prevent outbreaks of cholera in Japan, quarantine measures have been implemented to analyse stool samples from persons suspected of being infected with Vibrio cholerae.

For the diagnosis of cholera, immunological reversed passive latex particle agglutination (RPLA) and enzyme-linked oligonucleotide DNA probe [3] assays are used to detect cholera enterotoxin (CT)-producing $V$. cholerae isolates from stool and rectal swab specimens. Currently, specimens of stool and food are plated on agar and CT-producing $V$. cholerae $\mathrm{Ol}$ are identified by biochemical analysis, slide agglutination of $\mathrm{Ol}$ sero-

Received 30 Sept. 1998; accepted 3 Dec. 1998.

Corresponding author: K. Miyagi (e-mail: ksano@art. osakamed.ac.jp).

॥Present address: Kobe Quarantine Station, Kobe, Japan. typing and RPLA for CT detection. This routine diagnostic protocol, which requires c. 3 days, is too long.

A highly sensitive PCR assay has been applied to detect the gene for the CT subunit A $(\operatorname{ctx} A)$ of enteropathogenic $V$. cholerae [4-6]. Ramamurthy et al. [4] showed that PCR provided a sensitive and specific assay method for the rapid detection of toxigenic $V$. cholerae in faecal samples obtained by catheterisation. Varela et al. [5] also reported that the ctxA gene could be detected directly with high sensitivity in rectal swabs. In their study, they examined rectal samples obtained by invasive sampling procedures such as catheterisation and swabbing, although a direct faecal assay would be preferable, especially for mild cases and healthy carriers in nonendemic areas.

Stool specimens may contain materials that interfere with the PCR, as applied to studies with Salmonellae [7-9], enterohaemorrhagic Escherichia coli [10-14], Helicobacter pylori [15], Clostridium difficile [16] and $V$. cholerae $[4,5]$. In these studies, the activity of PCR inhibitors was removed or eliminated by enriched culture of bacteria $[7,8,13,15,17]$, centrifugation $[8$, $12,14]$, dilution $[4,5]$, clarification of bacteria by immunomagnetic beads $[8,9,15]$, filtration [12] and DNA purification $[10,11,16,17]$. 
The present study attempted to remove the inhibitors of PCR to establish a simple method for the preparation of faecal samples for the direct detection of $V$. cholerae $\operatorname{ctx} A$ gene by PCR.

\section{Materials and methods}

\section{Bacteria and culture}

$V$. cholerae $\mathrm{O} 1$ strain AQ1001 was obtained from the Osaka Airport Quarantine Station and grown in alkaline peptone water (APW; $\mathrm{pH} 8.2$ ) containing polypeptone $1 \% \mathrm{w} / \mathrm{v}$ and $\mathrm{NaCl} 1 \% \mathrm{w} / \mathrm{v}$. The number of bacterial cells was calculated by dilution and plating on nutrient agar. An original bacterial suspension was prepared at a density of $c .1 \times 10^{8} \mathrm{cfu} / \mathrm{ml}$ in saline. The other bacteria - i.e., $56 c t x A^{+}$and $15 c t x A^{-}$ strains of $V$. cholerae $01,29 c t x A^{-}$strains of $V$. cholerae non-O1, one $\operatorname{ctx} A^{+}$and $29 \operatorname{ctx} A^{-}$strains of $V$. mimicus, 30 strains of heat-labile enterotoxin (LT)- producing Escherichia coli and 10 strains each of $V$. parahaemolyticus, V. fluvialis, Shigella spp., Salmonella spp., Plesiomonas shigelloides and Aeromonas spp. had been isolated from travellers at the Quarantine Stations in Osaka and Narita Airports, and Kobe Port (Table 1). Strain $\mathrm{S} 7$ of $c t x A^{+} V$. cholerae non-O1 was obtained from the Laboratory of Culture Collection, Research Institute for Microbial Diseases, Osaka University.

\section{Experimental faecal specimen}

The experimental protocol used to characterise PCR inhibitors in heated stool samples is summarised in Fig. 1. In brief, a $V$. cholerae-free stool sample from a healthy adult was suspended in saline to a concentration of $10 \%(\mathrm{~g} / \mathrm{ml})$, and heated at $94^{\circ} \mathrm{C}$ for $5 \mathrm{~min}$. The suspension was centrifuged by graded spins for $3 \mathrm{~min}$ at $430 \mathrm{~g}, 1700 \mathrm{~g}$ and $3900 \mathrm{~g}$, and the supernate and respective pellets were mixed with the original volume

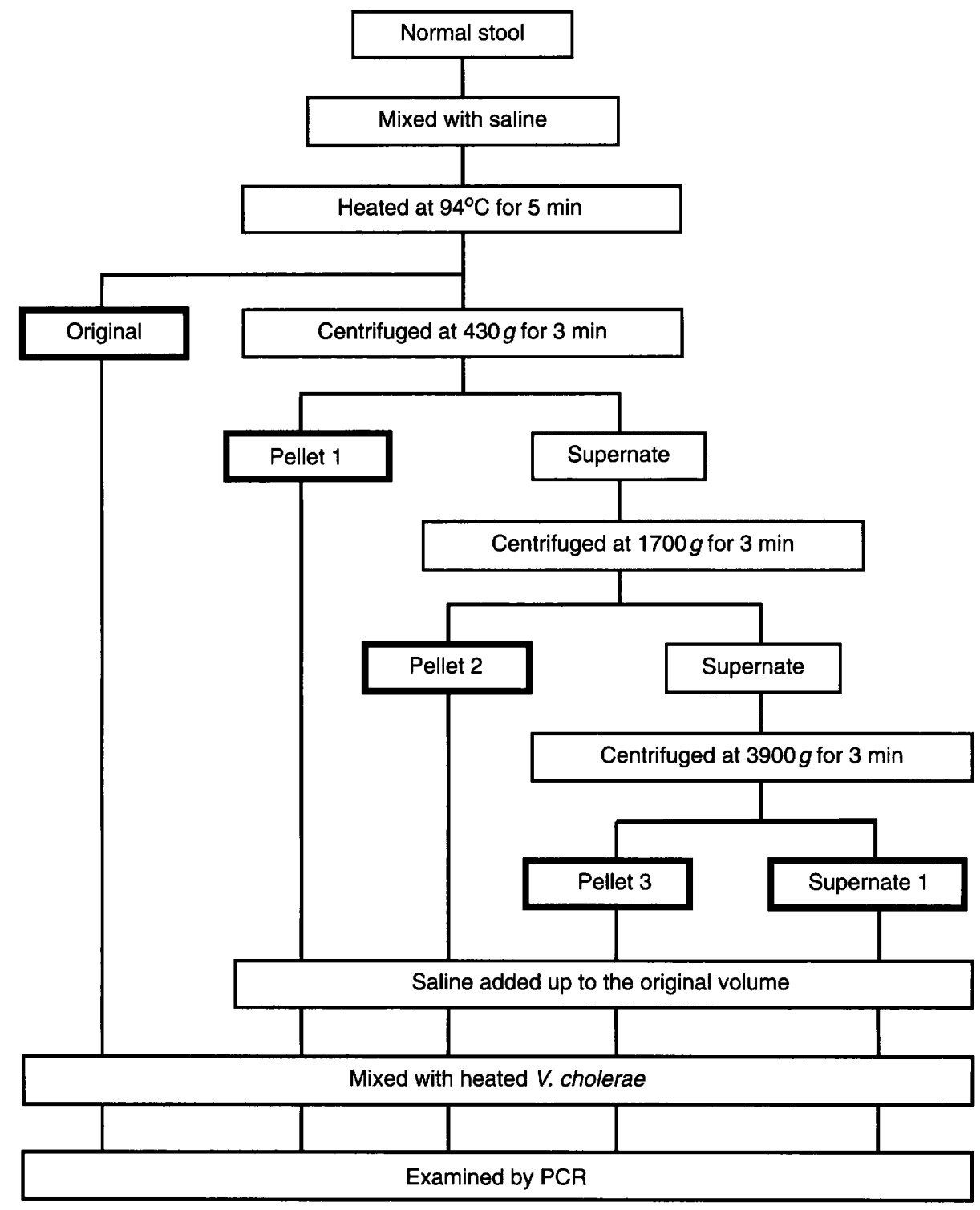

Fig. 1. Experimental design for identifying PCR inhibitors in faeces. Faecal specimens were separated as pellet 1 , pellet 2 , pellet 3 and supernate 1 by graded centrifugation. The original and each sample were mixed with heated $V$. cholerae O1 to a final concentration of $1 \times 10^{7} \mathrm{cfu} / \mathrm{ml}$ and assayed by PCR. 
of saline. To examine the inhibitory activity in this mixture, $90 \%$ of the volume of the mixture was added to the suspension of the clinical isolate of $V$. cholerae O1 strain AQ1001 heated at $94^{\circ} \mathrm{C}$ for $5 \mathrm{~min}$. The final mixtures were serially diluted and used as PCR samples.

\section{Clinical faecal specimen}

Stool samples were obtained from nine travellers known to be infected with $V$. cholerae $\mathrm{O} 1$ and 30 travellers with a history of diarrhoeal illness but from whom $V$. cholerae $\mathrm{O} 1$ had not been isolated by culture. Some specimens, in which PCR products could not be detected, were cultured in $10 \mathrm{ml}$ of $\mathrm{APW}$ at $37^{\circ} \mathrm{C}$ for $6 \mathrm{~h}$, and the cultures were used as PCR samples. The diluted stool and cultured stool samples were heated at $94^{\circ} \mathrm{C}$ for $5 \mathrm{~min}$, centrifuged at $1700 \mathrm{~g}$ for $3 \mathrm{~min}$ and examined for the presence of the $\operatorname{ctxA}$ gene in the supernate. The number of $V$. cholerae $\mathrm{O} 1$ bacteria was calculated by decimal dilution methods on thiosulphate citrate bile-salt sucrose (TCBS) agar plates. The number of yellow colonies was counted and these colonies were confirmed as positive for $\mathrm{O} 1$ antigen by slide agglutination with a polyvalent $\mathrm{Ol}$ rabbit antiserum.

\section{PCR}

A 372-bp section of the $c t x A$ gene was amplified with CTP-1 and CTP-2 primer pairs with the sequences $5^{\prime}-$ GGT CAA ACT ATA TTG TCT GGT C-3' and 5'ACT CAT CGA TGA TCT TGG AGC-3', respectively. These primers were purchased from Toyobo, (Osaka, Japan). Concentrated $(\times 10)$ reaction buffer $(10 \times \mathrm{RB})$ containing $15 \mathrm{mM} \mathrm{MgCl}_{2}, 800 \mathrm{mM} \mathrm{KCl}$, bovine serum albumin $5 \mathrm{~g} / \mathrm{ml}$, sodium cholate $1 \%$ and Triton $\mathrm{X}-100$ $1 \%$ in $100 \mathrm{mM}$ Tris-HCl buffer ( $\mathrm{pH} 8.9$ ) served as the PCR mixture. Tth DNA polymerase (Toyobo) was diluted in a buffer containing $300 \mathrm{mM} \mathrm{KCl}, 1 \mathrm{mM}$ dithiothreitol (DTT), $0.1 \mathrm{mM}$ EDTA, bovine serum albumin $500 \mu \mathrm{g} / \mathrm{ml}$, glycerol $50 \%$ and Triton $\mathrm{X}-100$ $0.1 \%$ in $10 \mathrm{mM}$ Tris-HCl buffer (pH 7.5) to a concentration of 2 unit/ $\mu 1$ of the enzyme. The PCR mixture was prepared in $0.5-\mathrm{ml}$ microtubes containing $5 \mu \mathrm{l}$ of the processed stool sample, $1 \mu 1$ of each primer solution $(40 \mathrm{pmol} / \mu \mathrm{l}), 5 \mu \mathrm{l}$ of $10 \times \mathrm{RB}, 5 \mu \mathrm{l}$ of $2 \mathrm{mM}$ dNTP solution and $1 \mu \mathrm{l}$ of enzyme solution in $32 \mu \mathrm{l}$ of distilled water. The mixture was overlaid with one drop of mineral oil, then centrifuged at $4500 \mathrm{~g}$ for $5 \mathrm{~s}$. Tubes were heated at $94^{\circ} \mathrm{C}$ for $1 \mathrm{~min}$ in a thermal cycler (Iwaki, Tokyo, Japan) and specific DNA sequences were amplified in a thermocycler with 30 cycles at $94^{\circ} \mathrm{C}, 58^{\circ} \mathrm{C}$ and $75^{\circ} \mathrm{C}$ for $25 \mathrm{~s}, 30 \mathrm{~s}$ and $20 \mathrm{~s}$, respectively. PCR products $(7 \mu \mathrm{l})$ were mixed with $3 \mu \mathrm{l}$ of loading buffer containing bromophenol blue $0.025 \%$, glycerol $5 \%$ and sucrose $7 \%$ in $50 \mathrm{mM}$ Trisacetate buffer ( $\mathrm{pH} 7.9$ ). The final mixture $(7 \mu \mathrm{l})$ was loaded on agarose $1.5 \%$ gel and electrophoresed for $c$. $35 \mathrm{~min}$ at $100 \mathrm{~V}$. The gel was stained with ethidium bromide $1 \mu \mathrm{g} / \mathrm{ml}$ at room temperature for $10 \mathrm{~min}$ and observed through a transilluminator with a wavelength of $312 \mathrm{~nm}$. A single band at $372 \mathrm{bp}$ was determined to be positive for the $c t x A$ gene. In some experiments, the intensity of brightness from the band was semiquantified by an optical gel analyser (MCID system, Imaging Res Inc., Ontario, Canada). The direct values obtained from the analyser were defined as relative units of intensity. The study further examined the specific PCR products by dot-blot hybridisation with a 30-mer enzyme-linked oligonucleotide probe (Toyobo) as described previously $[18,19]$.

\section{Determination of other enteropathogenic bacteria and cholera toxin (CT) assay}

Stool samples were also tested for the presence of other enteropathogenic bacteria by routine methods [20]. Isolates of $V$. cholerae, $V$. mimicus and other enteropathogenic bacteria used in the present study were cultured in casamino acid-yeast extract broth supplemented with lincomycin $90 \mu \mathrm{g} / \mathrm{ml}$ (CAYE-L) at $30^{\circ} \mathrm{C}$ overnight and then incubated with polymyxin $\mathrm{B}$ $20000 \mathrm{U} / \mathrm{ml}$ at $37^{\circ} \mathrm{C}$ for $2 \mathrm{~h}$. The incubated media were centrifuged at $1700 \mathrm{~g}$ for $20 \mathrm{~min}$ and the supernates were filtered through a $0.45-\mu \mathrm{m}$ pore membrane filter (Millipore, MA, USA). CT in the filtrate was assayed by RPLA with the CT assay kit (VET-RPLA, Denka Seiken, Tokyo, Japan) according to the manufacturer's instructions. RPLA-positive strains were considered to be CT-producing bacteria.

\section{Results}

The specificity of the PCR assay was compared with that of the RPLA assay for CT protein (Table 1). The PCR consistently differentiated $c t x A^{+}$strains of $V$. cholerae $\mathrm{O} 1$, non-O1 and $V$ mimicus from $\operatorname{ctx} A^{-}$ strains of vibrios and other enteropathogenic bacteria. The RPLA assay gave two false negative results with CT-producing $V$. cholerae O1 strains and $100 \%$ false positive results for LT-producing $E$. coli.

The removal of faecal PCR inhibitors was examined in faecal pellets with added $V$. cholerae $\mathrm{O} 1$ bacteria with $\operatorname{ctx} A$ detection by PCR. Semi-quantitative data, a representative photograph of gel-electrophoresed PCR products and calibration plots are shown in Table 2 and Fig. $2 a$ and $b$. As the relative unit of PCR product from the sample containing the pellet produced at $430 \mathrm{~g}$ was apparently the same as that from the sample containing the original stool (Table 2 and Fig. 2a), it was thought that the major inhibitors of PCR were contained in the pellet obtained from centrifugation at $430 \mathrm{~g}$ for $3 \mathrm{~min}$. The supernate from centrifugation at $3900 \mathrm{~g}$ still contained PCR inhibitor(s) (Table 2 and Fig. 2a). The supernate obtained after further centrifugation at up to $11000 \mathrm{~g}$ produced results similar to those obtained for samples centrifuged at $3900 \mathrm{~g}$ (data not shown). 
Table 1. Specificity of the primer pair used in the present study

\begin{tabular}{|c|c|c|c|}
\hline \multirow[b]{2}{*}{$c t x A$ positivity and organisms tested } & \multirow[b]{2}{*}{ Number of strains examined } & \multicolumn{2}{|c|}{ Number $(\%)$ of $c t x A / C T$ positive strains detected by } \\
\hline & & $\mathrm{PCR}^{*}$ & $\operatorname{RPLA}^{\dagger}$ \\
\hline \multicolumn{4}{|l|}{ Positive } \\
\hline$V$ cholerae $\mathrm{O} 1$ & 56 & $56(100)$ & $54(96.4)$ \\
\hline$V$ cholerae non-O1 & 1 & $1(100)$ & $1(100)$ \\
\hline$V$. mimicus & 1 & $1(100)$ & $1(100)$ \\
\hline \multicolumn{4}{|l|}{ Negative } \\
\hline V. cholerae $\mathrm{O} 1$ & 15 & $0(0)$ & $0(0)$ \\
\hline V. cholerae non-O1 & 29 & $0(0)$ & $0(0)$ \\
\hline$V$ mimicus & 29 & $0(0)$ & $0(0)$ \\
\hline LT-producing $E$. coli & 30 & $0(0)$ & $30(100)$ \\
\hline V. parahaemolyticus & 10 & $0(0)$ & $0(0)$ \\
\hline V. fluvialis & 10 & $0(0)$ & $0(0)$ \\
\hline Shigella spp. & 10 & $0(0)$ & $0(0)$ \\
\hline Salmonella spp. & 10 & $0(0)$ & $0(0)$ \\
\hline$P$ shigelloides & 10 & $0(0)$ & $0(0)$ \\
\hline Aeromonas spp. & 10 & $0(0)$ & $0(0)$ \\
\hline
\end{tabular}

* PCR products were detected by the identification of a single band on gel electrophoresis.

${ }^{\dagger}$ Bacteria were cultured in CAYE-L medium and CT was released by adding polymixin B. CT in culture supernate was detected with an RPLA kit.

Table 2. Physical characterisation of PCR inhibitors in faeces

\begin{tabular}{lcccccc}
\hline & \multirow{5}{*}{$\begin{array}{c}\text { Number of bacteria } \\
\text { Dilution of stool }\end{array}$} & \multicolumn{5}{c}{ Mean (SD) relative quantitative unit of PCR product* } \\
\cline { 2 - 7 } & Original $^{\dagger}$ & Pellet $1(430 \mathrm{~g})^{\dagger}$ & Pellet $2(1700 \mathrm{~g})^{\dagger}$ & Pellet $3(3900 \mathrm{~g})^{\dagger}$ & Supernate $1(3900 \mathrm{~g})^{\dagger}$ \\
\hline Undiluted $^{1}$ & $5 \times 10^{4}$ & $59.1(6.7)$ & $63.3(4.9)$ & $139.3(4.4)$ & $140.2(1.6)$ & $106.3(8.5)$ \\
$10^{1}$ & $5 \times 10^{3}$ & $114.4(5.1)$ & $127.0(3.0)$ & $131.9(2.7)$ & $126.5(5.4)$ & $130.4(0.7)$ \\
$10^{2}$ & $5 \times 10^{2}$ & $101.0(3.5)$ & $107.9(4.9)$ & $108.3(2.5)$ & $106.1(1.6)$ & $105.5(2.3)$ \\
\hline
\end{tabular}

${ }^{*}$ Brightness of the single band of PCR products was measured with an optical gel analyser (MCID, Imaging Res Inc.) and the values of the brightness provided by the system were represented. Mean (SD) of three samples.

${ }^{\dagger}$ Each numbered sample is identical to the original, pellets $1-3$ and supernate 1, respectively, as described in the experimental design (Fig. 1).

Although the amount of $\operatorname{ctx} A$ gene in the sample was decreased by dilution $(\times 10)$, the signals of PCR products were increased, owing to the dilution of PCR inhibitors in the supernate. Further dilution $(\times 10)$ reduced the sensitivity of the assay (Table 2 and Fig. 2a).

On the basis of these results, stool samples were prepared for the detection of $c t x A$ gene by a defined PCR assay method. The protocol for the assay was as follows: stool was diluted 10 times in saline, heated at $94^{\circ} \mathrm{C}$ for $5 \mathrm{~min}$, and centrifuged at $1700 \mathrm{~g}$ for $3 \mathrm{~min}$. Undiluted and diluted $(\times 10)$ supernates were subjected to 30 cycles of PCR and the PCR products were detected as a single band on gel electrophoresis or dotblot hybridisation, or both.

To evaluate the assay, nine clinical samples containing $c t x A^{+} V$. cholerae O1 were examined (Table 3). Five samples were positive for the $\operatorname{ctx} A$ gene as determined by gel electrophoresis or dot-blot hybridisation, or both (cases A, B, E, F and G). When the samples were diluted $(\times 10)$, three of four $c t x A$ false-negative samples became positive (cases $\mathrm{C}, \mathrm{H}$ and $\mathrm{I}$ ). When fresh stool samples were cultured for amplification of bacterial

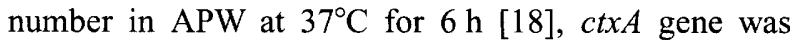
detected in the false-negative case D (Table 3). As expected, 30 stools containing $V$. cholerae non-O1, $V$. fluvialis, V. parahaemolyticus, Salmonella spp., Shigella spp., enteropathogenic E. coli, Plesiomonas shigelloides and Aeromonas sobria, that did not yield $V$. cholerae upon culture, did not give a positive reaction in the PCR for the $c t x A$ gene (Table 3, cases 1-30). The assay of the clinical sample could detect $0.85 \mathrm{cfu}$ of $V$. cholerae/assay in diluted stool samples containing $1.7 \times 10^{2} \mathrm{cfu} / \mathrm{ml}$ (Table 3 , case A).

\section{Discussion}

Rapid and accurate detection of enteropathogenic bacteria from the faeces is required for the diagnosis of enterocolitis. As the biochemical identification of bacterial isolates may take several days, a PCR assay was developed to reduce the time required for diagnosis. In the present study, a protocol was devised for the analysis of faecal samples for $\operatorname{ctx} A^{+} V$. cholerae by PCR assay in combination with gel electrophoresis and dot-blot hybridisation, and $\operatorname{ctx} A^{+} V$. cholerae was detected successfully in all CT-producing $V$. choleraepositive samples. As the assay yielded positive results in diluted samples and negative results in undiluted samples, and vice versa in a few cases (data not shown), it is recommended that both undiluted and diluted samples should be examined. When PCR products can be identified by gel electrophoresis, it 

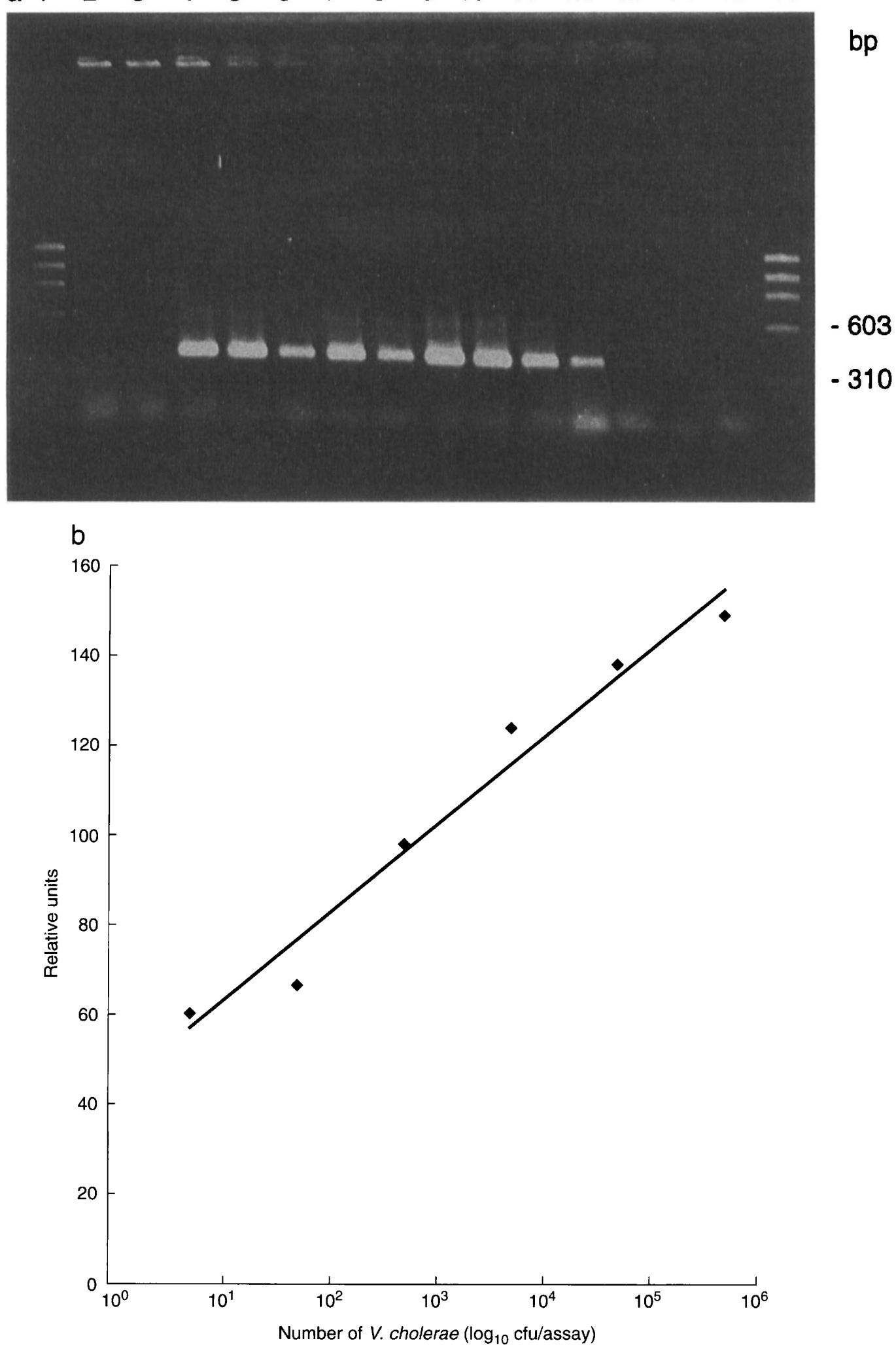

Fig. 2. (a) Representative photograph of gel electrophoresis. Lanes 1 and 16 are molecular size markers $(\phi X 174 /$ Hae III). Lanes 2-8 represent PCR inhibition by factors in experimental stool samples - 2, original; 3 , $430 \mathrm{~g}$ pellet; 4 , $1700 \mathrm{~g}$ pellet; $5,3900 \mathrm{~g}$ pellet; $6,3900 \mathrm{~g}$ supernate undiluted; 7, $3900 \mathrm{~g}$ supernate diluted (1 in 10$) ; \mathbf{8}, 3900 \mathrm{~g}$ supernate diluted ( 1 in 100). Lanes $\mathbf{9 - 1 4}$ represent calibration for semi-quantitative PCR with cells of strain AQ1001 $\mathbf{9}, 5 \times 10^{5}$ cells; $10,5 \times 10^{4}$ cells; $11,5 \times 10^{3}$ cells; $12,5 \times 10^{2}$ cells; $13,5 \times 10^{1}$ cells; $14,5 \times 10^{0}$ cells. Lane 15 is a negative control. All single bands of PCR products were quantified as described in Materials and methods. The values in relative units for calibration are plotted in Fig. $2 \mathrm{~b}$, and those for inhibition by stool factors are represented in Table 2. (b) Calibration for PCR products. The amounts of PCR products in relative units are fitted to the expression of $\mathrm{y}$ [relative unit $]=8.4762 \log _{10} \mathrm{x}[$ number of $V$. cholerae per assay $]-1.59\left(\mathrm{R}^{2}=0.97\right)$. 
Table 3. Specificity of the PCR assay for faecal samples

\begin{tabular}{|c|c|c|c|c|c|c|}
\hline \multirow[b]{2}{*}{ Case } & \multirow[b]{2}{*}{$\begin{array}{l}\text { Condition of } \\
\text { sample }\end{array}$} & \multirow[b]{2}{*}{$\begin{array}{l}\text { Number of } V \\
\text { cholerae in stool } \\
\text { (cfu/ml) }\end{array}$} & \multirow[b]{2}{*}{$\begin{array}{l}\text { Production of } \\
\text { CT by RPLA }\end{array}$} & \multirow[b]{2}{*}{$\begin{array}{l}\text { Other enteropathogenic } \\
\text { bacteria isolated* }\end{array}$} & \multicolumn{2}{|c|}{$\begin{array}{l}\text { Detectability of } c t x A \text { gene }^{\dagger} \\
\text { (sample dilution first positive) }\end{array}$} \\
\hline & & & & & $\begin{array}{l}\text { Single band on } \\
\text { gel electrophoresis }\end{array}$ & $\begin{array}{c}\text { Dot-blot } \\
\text { hybridisation }\end{array}$ \\
\hline A & Normal & $1.7 \times 10^{4}$ & + & None & $+\left(10^{1}\right)$ & $+\left(10^{0}\right)$ \\
\hline $\mathrm{B}$ & Loose & NT & + & None & - & $+\left(10^{\circ}\right)$ \\
\hline $\mathrm{C}$ & Loose & $5.9 \times 10^{5}$ & + & P. shigelloides, A. sobria & $+\left(10^{1}\right)$ & $+\left(10^{1}\right)$ \\
\hline D & Loose & $3.3 \times 10^{4}$ & + & None & - & - \\
\hline $\mathrm{D}^{\prime}$ & Cultured $d^{\S}$ & $1.4 \times 10^{6}$ & + & None & $+\left(10^{0}\right)$ & $+\left(10^{0}\right)$ \\
\hline $\mathrm{E}$ & Soft & $1.5 \times 10^{7}$ & + & P. shigelloides & $+\left(10^{0}\right)$ & $+\left(10^{0}\right)$ \\
\hline $\mathrm{F}$ & Watery & NT & + & None & $+(10)$ & $+\left(10^{0}\right)$ \\
\hline G & Watery & $1.7 \times 10^{8}$ & + & None & $+\left(10^{0}\right)$ & $+\left(10^{\circ}\right)$ \\
\hline $\mathrm{H}$ & Mucous & $8.7 \times 10^{8}$ & + & None & $+\left(10^{1}\right)$ & $+\left(10^{1}\right)$ \\
\hline I & Mucous & $1.7 \times 10^{5}$ & + & None & - & $+\left(10^{1}\right)$ \\
\hline $\mathrm{I}^{\prime}$ & Cultured ${ }^{\ddagger}$ & $2.2 \times 10^{7}$ & + & None & $+\left(10^{1}\right)$ & $+\left(10^{0}\right)$ \\
\hline $1 \& 2$ & Normal & 0 & NT & None & - & - \\
\hline $3 \& 4$ & Loose & 0 & NT & P. shigelloides & - & - \\
\hline 5 & Loose & 0 & NT & None & - & - \\
\hline \multirow[t]{2}{*}{6} & Soft & 0 & NT; & Salmonella spp., & - & - \\
\hline & Soft & & $\begin{array}{l}\text { NT } \\
\text { NT. }\end{array}$ & $\begin{array}{l}\text { P. shigelloides } \\
\text { Salmonella snn }\end{array}$ & - & - \\
\hline 7 & & 0 & $\begin{array}{l}\text { NT; } \\
\text { NT }\end{array}$ & & - & - \\
\hline \multirow[t]{3}{*}{$8 \& 9$} & Soft & 0 & NT; & Salmonella spp., & - & - \\
\hline & & & NT; & Enteropathogenic E. coli, & - & - \\
\hline & & & NT & P. shigelloides & - & - \\
\hline \multirow[t]{2}{*}{10} & Soft & 0 & NT & Salmonella spp., & - & - \\
\hline & & & - & V. cholerae non-O1 & - & - \\
\hline $11 \& 12$ & Soft & 0 & + & LT-producing $E$. coli & - & - \\
\hline \multirow[t]{2}{*}{13} & Soft & 0 & NT; & V. parahaemolyticus, & - & - \\
\hline & & & NT & P. shigelloides & - & - \\
\hline 14 & Soft & 0 & NT & V. parahaemolyticus & - & - \\
\hline 15 & Soft & 0 & NT & None & - & - \\
\hline \multirow[t]{3}{*}{16} & Watery & 0 & NT; & Salmonella spp., & - & - \\
\hline & & & $-;$ & $V$. cholerae non-O1, & - & - \\
\hline & & & NT & P. shigelloides & - & - \\
\hline \multirow[t]{2}{*}{17} & Watery & 0 & NT; & Salmonella spp., & - & - \\
\hline & & & NT & V. parahaemolyticus & - & - \\
\hline \multirow[t]{3}{*}{18} & Watery & 0 & NT; & Salmonella spp., & - & - \\
\hline & & & NT; & enteropathogenic $E$. coli; & - & - \\
\hline & & & NT & P. shigelloides & - & - \\
\hline $19 \& 20$ & Watery & 0 & NT & Salmonella spp. & - & - \\
\hline \multirow[t]{2}{*}{21} & Watery & 0 & NT & V. parahaemolyticus, & - & - \\
\hline & & 0 & NT & P. shigelloides & - & - \\
\hline 22 & Watery & 0 & NT & P. shigelloides & - & - \\
\hline 23 & Watery & 0 & NT & None & - & - \\
\hline \multirow[t]{2}{*}{24} & Mucous, & 0 & NT & Shigella spp., & - & - \\
\hline & bloody & & NT & A. sobria & - & - \\
\hline \multirow[t]{2}{*}{25} & Mucous, & 0 & NT & Shigella spp., & - & - \\
\hline & bloody & & - & V. cholerae non-O1 & - & - \\
\hline $26,27 \& 28$ & $\begin{array}{l}\text { Mucous, } \\
\text { bloody }\end{array}$ & 0 & NT & Shigella spp., & - & - \\
\hline 29 & $\begin{array}{l}\text { Mucous, } \\
\text { bloody }\end{array}$ & 0 & NT & V. parahaemolyticus & - & - \\
\hline 30 & $\begin{array}{l}\text { Mucous, } \\
\text { bloody }\end{array}$ & 0 & NT & None & - & - \\
\hline
\end{tabular}

NT: not tested.

* Other enteropathogenic bacteria detected by culture and biochemical analysis. None, no enteropathogenic bacteria was isolated.

$\dagger_{+}$, detectable; - , undetectable; the samples were diluted 10 -fold for preparation of the specimen.

${ }^{\ddagger}$ Cultured: the specimen was cultured at $37^{\circ} \mathrm{C}$ for $6 \mathrm{~h}$ to amplify the bacteria.

takes about $3 \mathrm{~h}$ to detect cholera toxin genes, but dotblots may take longer. The preparation of stool for PCR is simple, i.e., it requires only low-speed centrifugation, heating for denaturation and dilution of clinical specimens.

In comparison, the RPLA assay missed two strains of $c t x A^{+}$V. cholerae which were detected by PCR. Also, the superior specificity of PCR was demonstrated by the high false positivity of RPLA for LT-producing $E$. coli, because CT and LT have immunological crossreactivity [21]. The reason for this high rate of falsepositive results in the RPLA could be attributed to immunological cross-reactivity between the CT subunit A of $V$. cholerae and LT of E. coli [22]. Case A had received antibiotics and consequently the stool sample might be expected to contain large numbers of unculturable bacteria. Therefore, the sensitivity of this 
method in the examination of the clinical sample could not be included in the discussion.

In conclusion, the protocol described here provides a specific, simple and rapid test for providing evidence of faecal carriage of toxigenic $V$. cholerae.

We thank S. Takai, H. Hirose, A. Yoshida, K. Noda, H. Mori, N. Suzuki, Y. Ueda, T. Furukawa, N. Takahashi and Ms Y. Takegaki from Kansai Airport Quarantine Station, and K. Baba, S. Ito, M. Hanafusa, Ms A. Ogawa and Ms K. Mori from Osaka Quarantine Station for their advice on the experiments. We also thank Dr $\mathrm{H}$. Kato and T. Nagai for technical advice and Ms A. Sakata for assistance in the preparation of this manuscript. This work was partly supported by a grant for Scientific Research Expenses for Health and Welfare Program from the Ministry of Health and Welfare, Japan and a grant for Communicable Diseases from the City of Takatsuki, Japan.

\section{References}

1. WHO. Cholera in 1995. Wkly Epidemiol Rec 1996; 71: $157-163$.

2. WHO. Cholera in 1996. Wkly Epidemiol Rec 1997; 72: 229-235.

3. Yoh M, Miyagi K, Matsumoto $\mathrm{Y}$ et al. Development of an enzyme-labeled oligonucleotide probe for the cholera toxin gene. J Clin Microbiol 1993; 31 1312-1314.

4. Ramamurthy $\mathrm{T}, \mathrm{Pal} \mathrm{A}$, Bag PK et al. Detection of cholera toxin gene in stool specimens by polymerase chain reaction: comparison with bead enzyme-linked immunosorbent assay and culture method for laboratory diagnosis of cholera. $J$ Clin Microbiol 1993; 31: 3068-3070.

5. Varela P, Pollevick GD, Rivas $\mathrm{M}$ et al. Direct detection of Vibiro cholerae in stool samples. J Clin Microbiol 1994; 32: 1246-1248.

6. Vicente ACP, Coelho AM, Salles CA. Detection of Vibrio cholerae and $V$. mimicus heat-stable toxin gene sequence by PCR. J Med Microbiol 1997; 46: 398-402.

7. Chiu C-H, Ou JT. Rapid identification of Salmonella serovars in feces by specific detection of virulence genes, $\operatorname{inv} A$ and $s p v C$, by an enrichment broth culture-multiplex PCR combination assay. $J$ Clin Microbiol 1996; 34: 2619-2622.

8. Kongmuang U, Luk JMC, Lindberg AA. Comparison of three stool-processing methods for detection of Salmonella serogroups B, C2, and D by PCR. J Clin Microbiol 1994; 32: 3072-3074

9. Widjojoatmodjo MN, Fluit AC, Torensma R, Verdonk GPHT,
Verhoef $\mathrm{J}$. The magnetic immuno polymerase chain reaction assay for direct detection of Salmonellae in fecal samples. $J$ Clin Microbiol 1992; 30: 3195-3199.

10. Brian MJ, Frosolono M, Murray BE et al. Polymerase chain reaction for diagnosis of enterohemorrhagic Escherichia coli infection and hemolytic-uremic syndrome. J Clin Microbiol 1992; 30: $1801-1806$

11. Caprioli A, Luzzi I, Gianviti A, Russmann H, Karch H. Phenogenotyping of verotoxin 2 (VT2)-producing Escherichia coli causing haemorrhagic colitis and haemolytic uraemic syndrome by direct analysis of patient's stools. J Med Microbiol 1995; 43: $348-353$.

12. Cave H, Mariani P, Grandchamp B, Elion J, Denamur E. Reliability of PCR directly from stool samples: usefulness of an internal standard. Biotechniques 1994; 16: 809-810.

13. Paton AW, Paton JC, Goldwater PN, Manning PA. Direct detection of Escherichia coli Shiga-like toxin genes in primary fecal cultures by polymerase chain reaction. J Clin Microbiol 1993; 31: 3063-3067.

14. Ramotar K, Waldhart B, Church D, Szumski R, Louie TJ. Direct detection of verotoxin-producing Escherichia coli in stool samples by PCR. J Clin Microbiol 1995; 33: 519-524.

15. Enroth H, Engstrand L. Immunomagnetic separation and PCR for detection of Helicobacter pylori in water and stool specimens. J Clin Microbiol 1995; 33: 2162-2165.

16. Lou Q, Chong SKF, Fitzgerald JF, Siders JA, Allen SD, Lee C-H. Rapid and effective method for preparation of fecal specimens for PCR assays. J Clin Microbiol 1997; 35: 281-283.

17. Sidhu $\mathrm{H}$, Allison $\mathrm{M}$, Peck $\mathrm{AB}$. Identification and classification of Oxalobacter formingenes strains by using oligonucleotide probes and primers. J Clin Microbiol 1997; 35: 350-353.

18. Miyagi $\mathrm{K}$, Matsumoto $\mathrm{Y}$, Hayashi $\mathrm{K}$ et al. Cholera diagnosed in clinical laboratory by DNA hybridisation. Lancet 1992; 339: 988-989.

19. Miyagi K, Matsumoto Y, Hayashi K, Yoh M, Yamamoto K, Honda T. Successful application of enzyme-labeled oligonucleotide probe for rapid and accurate cholera diagnosis in a clinical laboratory. Microbiol Immunol 1994; 38: 301-304.

20. Abe $\mathrm{H}$, Kanda $\mathrm{T}$, Yanai $\mathrm{Y}$ et al. Bacteriological study of traveller's diarrhoea. (1) Isolation of enteric bacteria from patients with travellers' diarrhoea at Osaka Airport Quarantine Station during 1979. J Jpn Assoc Infect Dis 1981; 55: 679-690.

21. Honma Y, Higa N, Tsuji T, Iwanaga M. Comparison of a reversed passive latex agglutination and a polymerase chain reaction for identification of cholera toxin producing Vibrio cholerae O1. Microbiol Immunol 1995; 39: 59-61.

22. Clements JD, Finkelstein RA. Immunological cross-reactivity between a heat-labile enterotoxin(s) of Escherichia coli and subunits of Vibrio cholerae enterotoxin. Infect Immun 1978; 21: $1036-1039$. 